\title{
Usutu virus - potential risk of human disease in Europe
}

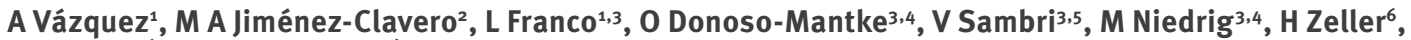 \\ A Tenorio (atenorio@iscii.es) ${ }^{1,3}$ \\ 1. National Microbiology Centre, Instituto de Salud Carlos III, Madrid, Spain \\ 2. Instituto Nacional de Investigación y Tecnología Agraria y Alimentaria (INIA, National Institute of Research and Agricultural \\ Technology and Food), Madrid, Spain \\ 3. European Network for Diagnostics of Imported Viral Diseases - Collaborative Laboratory Response Network (ENIVD-CLRN) \\ 4. Robert Koch Institute, Berlin, Germany \\ 5. Regional Reference Centre for Microbiological Emergencies (CRREM), Unit of Clinical Microbiology, St Orsola University \\ Hospital, University of Bologna, Bologna, Italy \\ 6. European Centre for Disease Prevention and Control (ECDC), Stockholm, Sweden
}

Citation style for this article:

Vázquez A, Jiménez-Clavero MA, Franco L, Donoso-Mantke O, Sambri V, Niedrig M, Zeller H, Tenorio A. Usutu virus - potential risk of human disease in Europe. Euro Surveill. 2011;16(31):pii=19935. Available online: http://www.eurosurveillance.org/ViewArticle.aspx?Articleld=19935

Usutu virus (USUV) is an African mosquito-borne flavivirus, member of the Japanese encephalitis antigenic group. This avian virus is transmitted by arthropod vectors (mainly mosquitoes of the Culex pipiens complex). It is well known that free-living birds, including migratory species, have the potential to disperse certain pathogenic microorganisms. Usutu virus has recently been introduced to Europe and is spreading through Austria, Hungary, Italy, Spain and Switzerland, causing disease in birds and humans. Like West Nile virus, USUV may become a resident pathogen in Europe and the consequences for public health should be considered. Many different biotic and abiotic factors affect the survival of the virus in a new environment and influence the efficiency of its geographical dispersal. In this article, we consider the possibility of including USUV infections among the vector-borne diseases to be monitored in Europe.

\section{Background}

Usutu virus (USUV) is an African mosquito-borne virus of the family Flaviviridae, genus Flavivirus, belonging to the Japanese encephalitis serocomplex [1]. From an ancestral flavivirus with a bird/mosquito natural cycle evolved the different flaviviral species present today, such as USUV and West Nile virus (WNV) in Africa, Asia and Europe, Japanese encephalitis virus (JEV) in Asia, Murray Valley encephalitis virus in Australia and Saint Louis encephalitis virus in the American continent. USUV was originally isolated from a mosquito (Culex neavei) in 1959 in South Africa. Further USUV strains were detected from different bird and mosquito species in Africa in subsequent years, but human disease (rash and fever) has only been reported once, in the Central African Republic $[2,3]$. In the past, USUV was not considered as a potential threat for humans because the virus had never been associated with severe or fatal diseases in animals or humans, and it had never before been observed outside tropical and subtropical Africa.

\section{Avian, horse and vector surveillance}

In the summer of 2001, USUV emerged in Austria, causing deaths in several species of resident birds, especially among birds of the order Passeriformes [4-6]. In the following years, the virus has been detected in dead birds and/or mosquitoes in several countries, including Hungary (2005) [7], Italy (2009) [8], Spain (2006 and 2009) [9,10] and Switzerland (2006) [11]. USUV infection has also been demonstrated serologically in wild bird hosts in the Czech Republic (2005) [12], England (2001-2002) [13], Germany (2007) [14], Italy (2007) [15], Poland (2006) [16], Spain (2003-2006) [17] and Switzerland (2006) [18] (Figure). The recurrence of the virus over several years in Austria (2001-2006) [19], Hungary (2003-2006) [7], Italy (2006-2008) [8] and Spain $(2006,2009)[9,10]$ suggests either frequent reintroduction of the virus or, more likely, persistence of the transmission in the affected areas, possibly through overwintering mosquitoes. Comparisons of pathologic alterations revealed similar lesions in birds infected in the Austrian, Hungarian, Italian and Swiss USUV outbreaks, and these findings were supported by partial nucleotide sequence analysis with $>99 \%$ identity between the viruses which emerged in Vienna in 2001, in Budapest in 2005, and in Zurich and Milan in 2006. A one-time introduction of USUV from Africa to Europe (Vienna) is therefore highly likely, and this particular strain has since been spreading in Central Europe [11]. However, a two-year study carried out in 2008 to 2009 in Italy to monitor the USUV circulation within the West Nile Disease (WND) national surveillance plan suggests a different scenario [20]. In that work, sentinel horses and chickens, wild birds and mosquitoes were sampled and tested for serological and virological evidence of USUV. Seroconversion in sentinel animals proved that the virus had circulated in Italy in these two years. In addition, the study demonstrated USUV infection in horses for first time in Europe. Sequence comparison of USUV detected from different species in different counties showed that two different strains of USUV are likely to have circulated in Italy between 2008 and 
2009, and these strains have adapted to new hosts and vectors to become established in new areas.

\section{Recent human cases and} clinical characteristics

In the end of the summer 2009, the virus was associated with neurological disorders in two immunocompromised patients (both had received blood transfusions) in Italy [21,22]. In addition, USUV was isolated from the blood obtained from one of these subjects during the acute stage of disease. The patients were detected concurrently with the active surveillance programme of blood and organ donations that the public health authority of the Emilia Romagna region had initiated in August 2008, based on several veterinary and entomological reports of WNV circulation in north-eastern Italy [23]. The two infections could be consistent with local transmission, either directly through a mosquito bite or indirectly through an infected donor. Both patients had in common that they were immunosuppressed and had received blood transfusions in the same period of time (August 2009). As transmission for WNV through blood products and transplantation has been documented [24,25], screening for WNV was performed of blood samples and organ donations from 15 June to 31 October, with negative results. The two patients were the first human cases of USUV neuroinvasive illness described worldwide. The common clinical symptoms were persistent fever of $39.5{ }^{\circ} \mathrm{C}$, headache and neurological disease (impaired neurological functions). One patient developed a fulminant hepatitis, a pathology that had been described previously in rare cases of WNV infection [26,27]. In both patients, the clinical picture was similar, with a clear involvement of the central nervous system, resembling the related WNV neuroinvasive disease. Whether this new tropism was associated with new characteristics of the infecting viruses, with a possible inoculation route through transfusion, and/or to the underlying diseases of the patients still remains unclear, but these findings reinforce the need for further investigations. The partial sequences obtained from cerebrospinal fluid (CSF) and plasma samples of these patients were more than $98 \%$ identical with the viruses that had emerged in Vienna and Budapest (in 2001 and 2005, respectively) $[21,22]$. In a recent phylogenetic study of sequences of USUV strains obtained in Italy in 2009 from mosquitoes, birds and humans, the sequences obtained from human hosts clustered with the sequences obtained from birds, which would indicate an endemic distribution of USUV in Europe [20].

\section{Diagnostics}

Clinical suspicion of USUV infection requires laboratory confirmation. Within laboratory methods, we can distinguish between direct methods (detecting the virus by cell culture or genomic amplification) and indirect methods (detect the antibody response to the infection). Serological diagnosis of USUV infections in humans will require an approach similar to the one used for WNV. Although there is a lack of experience about
USUV infection in humans, it is assumed that its incubation period will be two to 14 days, that USUV will be detectable in CSF and serum in the acute stage of the disease, and that IgM antibodies will appear five days after onset of fever, in analogy to the current knowledge about the pathogenesis of WNV-related illness in humans. Antibodies may persist in serum for many months after infection [28]. Diagnosis of USUV will not be easy, particularly in areas where circulation along with others cross-reacting flaviviruses occur. That is the case for WNV and tick-borne encephalitis virus in several European countries [29]. Until more specific diagnostic methods are developed and made available for diagnostic laboratories, antibody detection could be carried out using cross-reacting ELISA methods designed for WNV diagnosis. It is also expected that cross-reactivity will be higher for IgG than for IgM detection; consequently, development of tests for USUV-specific IgM is needed more urgently. As an already available alternative, acute and convalescent sera should be tested for seroconversion of IgG antibodies using in-house or commercial ELISA tests based on WNV antigens. Cross-reactions can be resolved by parallel titrations against various flaviviruses in assays for neutralising antibodies, which are more specific

\section{FIGURE}

Diagnostic capacities for Usutu virus in European countries in the ENIVD network and detection of the virus in mosquitoes, birds, horses and/or humans

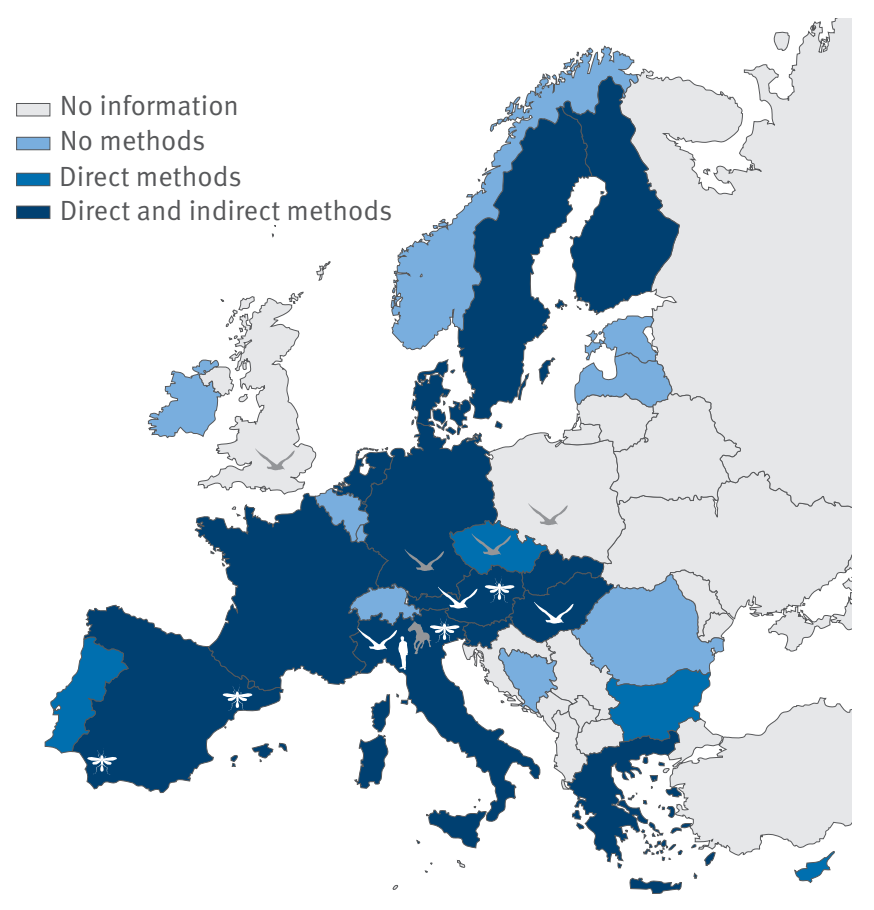

ENIVD: European Network for Diagnostics of Imported Viral Diseases.

Colour code indicates diagnostic capacities: direct methods detect the virus by cell culture or genomic amplification, indirect methods detect the antibody response to the infection.

Animal symbols indicate detection of Usutu virus in these species: geographical distribution is indicated either by virus detection (species in white) or by evidence of neutralising antibodies (dark grey). 
than ELISAs but can be performed only in specialised laboratories that can handle hazardous viruses [30].

The possibility of USUV to infect and cause severe neurological syndromes in humans makes it necessary to develop new affordable and rapid molecular methods for its detection. Recently, a specific real-time RT-PCR assay has been developed to identify USUV in human plasma, serum and CSF samples. This technique has allowed the detection of USUV in three CSF specimens that were collected in the summers of 2008 and 2009 from 44 patients with suspected meningoencephalitis and were negative for WNV [31]. However, serological testing is still needed and important to identify infection after the viraemic stage. In Europe, most of the countries are prepared for detecting USUV genome in human or bird samples (Figure), generally using crossreactive or generic methods for detecting flaviviruses. More specific techniques are required, especially for those countries with direct evidence for WNV and/or USUV circulation (Austria, Belarus, Bulgaria, Czech Republic, France, Hungary, Italy, Moldova, Portugal, Romania, Russia, Slovakia, Spain and Ukraine) [32], and new methods are being designed to identify and distinguish USUV from other arboviruses, particularly from members of the JEV group that have been circulating in Europe [31,33]. In fact, a false-positive result of a WNV RT-PCR was reported in Italy in 2009 in a patient with viraemia caused by USUV [23].

\section{Surveillance and control}

The number of recent notifications of mosquito-borne diseases in the European Union in 2010 is a reason for concern. These events involved different types of pathogens like WNV, USUV, dengue virus, chikungunya virus and Plasmodium sp, some of which are considered typical for tropical areas. This current situation triggered a request from the European Commission for a risk assessment [34]. The overall objective of this consultation was to acquire a comprehensive understanding of the transmission potential for mosquito-borne diseases in Europe in order to propose recommendations for preparedness actions. The final conclusion was to develop a tool for decision making in WNV infection preparedness and control, which would guide countries through the complexities of responding to any alerts or outbreaks of this disease.

In Europe, WNV re-emerged in Romania, where it was first associated to neurological disease [35]. Since then, the virus has been detected with increasing activity in several European countries [36], including Italy, where it was circulating at least in 2008 and 2009, with eight and 16 human cases, respectively, of West Nile neuroinvasive disease [37]. Because of WNV circulation in Italy with neuroinvasive cases in humans and horses [38,39], a regional surveillance plan was implemented starting from 2008 [40]. Thanks to, these WNV surveillance activities antibodies against WNV and USUV were detected in Italy in 2009 in sentinel animals (horses and chickens), wild birds and provided evidence of cocirculation of WNV and USUV in mosquitoes and birds in the same area $[20,41,42]$.

That five human USUV infections have recently been detected in areas where an effective surveillance for WNV exists, suggest that this disease may also be under-recognised in some other areas where the surveillance for WNV is lacking or poorly implemented. Both viruses seem to be able to cause neurological disease in humans under certain circumstances. The emergence of USUV in Europe, even if not presently considered a major threat warrants the enhancement of surveillance plans for neuroinvasive illness during the summer season, corresponding to the peak of activity of potential vectors. The extension of surveillance to flaviviruses other than WNV will require new diagnostic procedures and the development of more specific serological tests that can be used in the field [42]. As WNV and USUV viruses share many eco-epidemiological and virological characteristics, WNV surveillance programmes could be easily adapted to survey also USUV in birds, horses, mosquitoes and human samples. This approach should be based on the development of adequate and standardised differential laboratory diagnosis using validated methods (serological and molecular) enabling the differential detection of WNV and USUV infections, especially in those countries with demonstrated co-circulation of both viruses (at least Austria, Hungary, Italy, and Spain). A specific realtime RT-PCR assay to identify USUV in human plasma, serum, and CSF that has been developed [31] is very helpful for donor screening and diagnostics. Some of the molecular techniques designed to detect WNV can also amplify the signal for USUV due to false positive results by lack of specificity in the technique.

A surveillance programme for USUV in Europe could be very similar to national surveillance systems for WNV that are already implemented in some countries in Europe. In fact, in those European countries which have implemented a national WNV surveillance plan, this could be used in parallel for USUV surveillance. These programmes consist of human, veterinary and entomological surveillance. The objective of passive and active human surveillance systems would be the early detection of infection in humans. This activity should be performed by serology and/or detection of the viral genome in blood and cerebrospinal fluid from all suspected cases suffering from acute meningoencephalitis. In this regard, it would be important to raise the awareness of clinicians for this emerging disease, which may improve the sensitivity of the surveillance system. Since the diagnosis of encephalitis is of general importance, the inclusion of USUV diagnostics for differential diagnosis in cases of unknown origin should be considered for extended screening of aetiologies. Key requirements for a possible future surveillance study at European level have already been suggested [30]. Animal surveillance should be performed on the basis of passive and active surveillance of horses and non-migratory wild birds. Entomological 
surveillance should be based on the weekly to monthly (frequency depending on local resources) collection of mosquitoes in fixed stations and at sites where USUV activity has been demonstrated ascertained in birds, humans or horses.

As suggested by Chvala et al. [5], mosquito monitoring and screening of wild birds are suitable to detect USUV circulation and could replace surveillance of dead birds when bird mortality drops because of herd immunity. Although virological surveillance (with molecular techniques) may be preferable over serological monitoring because it avoids cross-reactions with other flaviviruses, they are impeded by shortlived viraemia, when serology is still possible due to long-lasting serum antibodies. Sera reacting to both WNV and USUV were detected in other studies using tests with low specificity such as haemagglutination inhibition [19] or ELISA [15]. Plaque reduction neutralisation has to be performed to confirm positive sera, but this test is complex, costly, time-consuming and not accessible for laboratories lacking high biocontainment facilities.

As for WNV, surveillance of wild birds and vectors will be used in the coming years to forecast the spread of USUV. The information gathered will be used to develop actions to prevent virus transmission, such as vector monitoring and control, information campaigns to improve personal protection, and screening tests for donor blood, tissue and organs.

\section{Conclusions}

In Europe the risk exists that potential emerging infectious diseases, such as those caused by WNV or USUV, will not be recognised in time by existing surveillance infrastructures of the various European countries [43]. As treatments for USUV and WNV are not available, there is a need to strengthen surveillance. Circulation of USUV in Austria, Hungary, Italy and Spain during consecutive years and seroconversions reported recently in sentinel animals and detection of virus in wild birds in Italy, show that these territories are suitable to support USUV circulation between vectors and vertebrate hosts, as well as overwintering, enabling the establishment of endemic cycles. This indicates a need to organise standard surveillance measures and early warning systems to detect WNV and USUV activity, and to assess the risk for public health. Establishing a European surveillance system by grouping the existing resources and introducing a standardised reporting and diagnostic system is essential for future preparedness and response. This surveillance system should be sensitive and able to detect USUV and WNV circulation at an early stage. A multidisciplinary approach should be considered when evaluating the risk of USUV and WNV transmission, and the contribution of the different components (mosquitoes, birds, horses, humans) should be carefully assessed.
Acknowledgements

The ENIVD is part of the ECDC "Outbreak Assistance Laboratory Network" and received funding as the ENIVD Collaborative Laboratory Response Network (ENIVD-CLRN) under the contract no. ECDC/2008/011. We are indebted for the participation of the ENIVD-CLRN members: Aberle S, Austria; Alves MJ, Portugal; Avšič T, Slovenia; Barzon L, Italy; Ceianu C, Romania; Charrel R, France; Christova I, Bulgaria; Ciufolini MG, Italy; Connell J, Ireland; Detlev S, Switzerland; Di Caro A, Italy; Dobler G, Germany; Doornum G, Netherlands; Dudman S, Norway; Emőke F, Hungary; Eßbauer S, Germany; Grandadam M, France; Griskevicius A, Italy; Heyman P, Belgium; Hukic M, Bosnia and Herzegovina; Klempa B, Slovakia; Kolupajeva T, Latvia; Leparc-Goffart I, France; Kostrikis LG, Cyprus; Lundkvist A, Sweden; Monaco F, Italy; Opp M, Luxembourg; Papa A, Greece; Pfeffer M, Germany; Sánchez-Seco MP, Spain; Schutten M, Netherlands; Van Esbroeck M, Belgium; Vapalahti O, Finland; Zelená H, Czech Republic.

\section{References}

1. Kuno G, Chang GJ, Tsuchiya KR, Karabatsos N, Cropp CB. Phylogeny of the genus Flavivirus. J Virol. 1998;72(1):73-83.

2. Williams MC, Simpson DI, Haddow AJ, Knight EM. The isolation of West Nile Virus from man and of Usutu virus from the birdbiting mosquito Mansonia aurites (Theobald) in the Entebbe area of Uganda. Ann Trop Med Parasitol. 1964;58:367-74.

3. Adam F, Digouette JP. Virus d'Afrique (base de données) [Viruses of Africa (database)]. Dakar: World Health Organization Collaborating Reference and Research Centre for arboviruses and haemorrhagic fever viruses (CRORA), Institut Pasteur de Dakar; Jul 2005. Available from http://www.pasteur. $\mathrm{fr} /$ recherche/banques/CRORA

4. Weissenböck H, Kolodziejek J, Fragner K, Kuhn R, Pfeffer M, Nowotny N. Usutu virus activity in Austria, 2001-2002. Microbes Infect. 2003;5(12):1132-6.

5. Chvala S, Bakonyi T, Bukovsky C, Meister T, Brugger K, Rubel $\mathrm{F}$, et al. Monitoring of Usutu virus activity and spread by using dead bird surveillance in Austria, 2003-2005. Vet Microbiol. 2007;122(3-4):237-45.

6. Weissenböck H, Kolodziejek J, Url A, Lussy H, RebelBauder B, Nowotny N. Emergence of Usutu virus, an African mosquitoborne flavivirus of the lapanese encephalitis virus group, central Europe. Emerging Infect Dis. 2002;8(7):652-6.

7. Bakonyi T, Erdélyi K, Ursu K, Ferenczi E, Csörgo T, Lussy H, et al. Emergence of Usutu Virus in Hungary. J Clin Microbiol. 2007;45(12):3870-4.

8. Manarolla G, Bakonyi T, Gallazzi D, Crosta L, Weissenböck H, Dorrestein GM, et al. Usutu virus in wild birds in northern Italy. Vet Microbiol. 2010;141(1-2):159-63.

9. Busquets N, Alba A, Allepuz A, Aranda C, Núñez JI. Usutu Virus Sequences in Culex pipiens (Diptera: Culicidae), Spain. Emer Infect Dis. 2008;14(5):861-3.

10. Vázquez A, Ruiz S, Herrero L, Moreno J, Molero F, Magallanes $A$, et al. West Nile and Usutu viruses in mosquitoes in Spain, 2008-2009. Am J Trop Med Hyg. 2011;85(1):178-81.

11. Steinmetz HW, Bakonyi T, Weissenböck H, Hatt JM, Eulenberger $\mathrm{U}$, Robert N, et al. Emergence and establishment of Usutu virus infection in wild and captive avian species in and around Zurich, Switzerland-genomic and pathologic comparison to other central European outbreaks. Vet Microbiol. 2011;148(2-4):207-12

12. Hubálek Z, Halouzka J, Juricová Z, Sikutová S, Rudolf I, Honza $M$, et al. Serologic survey of birds for West Nile flavivirus in southern Moravia (Czech Republic). Vector Borne Zoonotic Dis. 2008;8(5):659-66.

13. Buckley A, Dawson A, Gould EA. Detection of seroconversion to West Nile virus, Usutu virus and Sindbis virus in UK sentinel chickens. Virol J. 2006;3:71.

14. Linke S, Niedrig M, Kaiser A, Ellerbrok H, Müller K, Müller T, et al. Serologic evidence of West Nile virus infections in wild birds captured in Germany. Am J Trop Med Hyg. 2007;77(2):358-64.

15. Lelli R, Savini G, Teodori L, Filipponi G, Di Gennaro A, Leone A, et al. Serological evidence of USUTU virus occurrence in northeastern Italy. Zoonoses Public Health. 2008;55(7):361-7. 
16. Hubálek Z, Wegner E, Halouzka J, Tryjanowski P, Jerzak L, Sikutová S, et al. Serologic survey of potential vertebrate hosts for West Nile virus in Poland. Viral Immunol. 2008;21(2):247-53.

17. Figuerola J, Soriguer R, Rojo G, Gómez Tejedor C, JimenezClavero MA. Seroconversion in wild birds and local circulation of West Nile virus, Spain. Emerg Infect Dis. 2007;13(12):1915-7.

18. Steinmetz HW, Bakonyi T, Chvala S, Weissenböck H, Eulenberger U, Hatt JM, et al. Emergence of Usutu virus in Switzerland. Proceedings 43rd international symposium on diseases of zoo and wild animals; 16-20 May 2007; Edinburgh. P. 129-31.

19. Meister T, Lussy H, Bakonyi T, Sikutová S, Rudolf I, Vogl W, et al. Serological evidence of continuing high Usutu virus (Flaviviridae) activity and establishment of herd immunity in wild birds in Austria. Vet Microbiol. 2008;127(3-4):237-48.

20. Savini G, Monaco F, Terregino C, Di Gennaro A, Bano L, Pinoni $C$, et al. Usutu virus in Italy: An emergence or a silent infection? Vet Microbiol. 2011;151(3-4):264-74.

21. Cavrini F, Gaibani P, Longo G, Pierro AM, Rossini G, Bonilauri $P$, et al. Usutu virus infection in a patient who underwent orthotropic liver transplantation, Italy, August-September 2009. Euro Surveill. 2009;14(50):pii: 19448. Available from: http://www.eurosurveillance.org/ViewArticle. aspx?Articleld $=19448$

22. Pecorari M, Longo G, Gennari W, Grottola A, Sabbatini A, Tagliazucchi S, et al. First human case of Usutu virus neuroinvasive infection, Italy, August-September 2009. Euro Surveill. 2009;14(14):pii: 19446. Available from: http://www. eurosurveillance.org/ViewArticle.aspx?Articleld =19446

23. Gaibani P, Pierro AM, Cavrini F, Rossini G, Landini MP, Sambri V. False-positive transcription-mediated amplification assay detection of West Nile virus in blood from a patient with viremia caused by an Usutu virus infection. J Clin Microbiol. 2010;48(9):3338-9.

24. Iwamoto M, Jernigan DB, Guasch A, Trepka MJ, Blackmore CG, Hellinger WC, et al. Transmission of West Nile virus from an organ donor to four transplant recipients. N Engl J Med. 2003;348(22):2196-203.

25. Pealer LN, Marfin AA, Petersen LR, Lanciotti RS, Page PL, Stramer SL, et al. Transmission of West Nile virus through blood transfusion in the United States in 2002. N Engl J Med. 2003;349(13):1236-45.

26. Campbell GL, Marfin AA, Lanciotti RS, Gubler DJ. West Nile virus. Lancet Infect Dis. 2002;2(9):519-29.

27. Georges AJ, Lesbordes JL, Georges-Courbot MC, Meunier DM, Gonzalez JP. Fatal hepatitis from West Nile virus. Ann Inst Pasteur Virol. 1987;138:237-44.

28. Solomón T. Flavivirus encephalitis. N Engl J Med. 2004;351:370-8.

29. Süss J. Tick-borne encephalitis in Europe and beyond-the epidemiological situation as of 2007. Euro Surveill. 2008 13(26):pii: 18916. Available from: http://www.eurosurveillance. org/ViewArticle.aspx?Articleld=18916

30. Donoso Mantke O, Vaheri A, Ambrose H, Koopmans M, de Ory $\mathrm{F}$, Zeller $\mathrm{H}$, et al. Analysis of the surveillance situation for viral encephalitis and meningitis in Europe. Euro Surveill. 2008;13(3):pii: 8017. Available from: http://www. eurosurveillance.org/ViewArticle.aspx?Articleld =8017

31. Cavrini F, Della Pepa ME, Gaibani P, Pierro AM, Rossini G, Landini MP, et al. A rapid and specific real-time RT-PCR assay to identify Usutu virus in human plasma, serum, and cerebrospinal fluid. J Clin Virol. 2011;50(3):221-3.

32. Hubálek Z. Mosquito-borne viruses in Europe. Parasitol Res. 2008;103 (Suppl 1):S29-43.

33. Johnson N, Wakeley PR, Mansfield KL, McCracken F, Haxton B, Phipps LP, et al. Assessment of a novel real-time pan-flavivirus RT-polymerase chain reaction. Vector Borne Zoonotic Dis. 2010;10(7):665-71.

34. European Centre for Disease Prevention and Control (ECDC). Expert consultation on West Nile virus infection, Stockholm, 21-22 April 2009. Meeting report. Stockholm: ECDC; 2009. Available from: http://www.ecdc.europa.eu/en/publications/ Publications/0909_MER_Expert_consultation_on_WNV.pdf

35. Cernescu C, Ruță SM, Târdei G, Grancea C, Moldoveanu L, Spulbăr E, et al'. A high number of severe neurologic clinical forms during an epidemic of West Nile virus infection. Rom J Virol. 1997;48(1-4):13-25.

36. Calistri P, Giovannini A, Hubalek Z, Ionescu A, Monaco F, Savini G, et al. Epidemiology of West Nile in Europe and in the Mediterranean basin. Open Virol J. 2010;4:29-37.
37. Rizzo C, Vescio F, Declich S, Finarelli AC, Macini P, Mattivi A et al. West Nile virus transmission with human cases in Italy, August - September 2009. Euro Surveill. 2009;14(41):pii: 19353. Available from: http://www.eurosurveillance.org/ ViewArticle.aspx?Articleld $=19353$

38. Macini P, Squintani G, Finarelli AC, Angelini P, Martini E, Tamba $M$, et al. Detection of West Nile virus infection in horses, Italy, September 2008. Euro Surveill. 2008;13(39):pii: 18990. Available from: http://www.eurosurveillance.org/ViewArticle. aspx?Articleld $=18990$

39. Rossini G, Cavrini F, Pierro A, Macini P, Finarelli AC, Po C, et al. First human case of West Nile virus neuroinvasive infection in Italy, September 2008 - case report. Euro Surveill. 2008;13(41): pii: 19002. Available from: http://www. eurosurveillance.org/ViewArticle.aspx?Articleld=19002

40. Angelini $P$, Tamba M, Finarelli AC, Bellini R, Albieri A, Bonilauri $P$, et al. West Nile virus circulation in EmiliaRomagna, Italy: the integrated surveillance system 2009. Euro Surveill. 2010;15(16):pii: 19547. Available from: http://www. eurosurveillance.org/ViewArticle.aspx?Articleld=19547

41. Calzolari M, Bonilauri P, Bellini R, Albieri A, Defilippo F, Maioli $\mathrm{G}$, et al. Evidence of simultaneous circulation of west nile and usutu viruses in mosquitoes sampled in emilia-romagna region (Italy) in 2009. PLoS One. 2010;5(12):e14324.

42. Tamba M, Bonilauri P, Bellini R, Calzolari M, Albieri A, Sambri $V$, et al. Detection of Usutu Virus Within a West Nile Virus Surveillance Program in Northern Italy. Vector Borne Zoonotic Dis. 2011;11(5):551-7.

43. Ahmed J, Bouloy M, Ergonul O, Fooks A, Paweska J, Chevalier $\mathrm{V}$, et al. International network for capacity building for the control of emerging viral vector-borne zoonotic diseases: ARBO-ZOONET. Euro Surveill. 2009;14(12):pii: 19160. Available from: http://www.eurosurveillance.org/ViewArticle. aspx?Articleld $=19160$ 